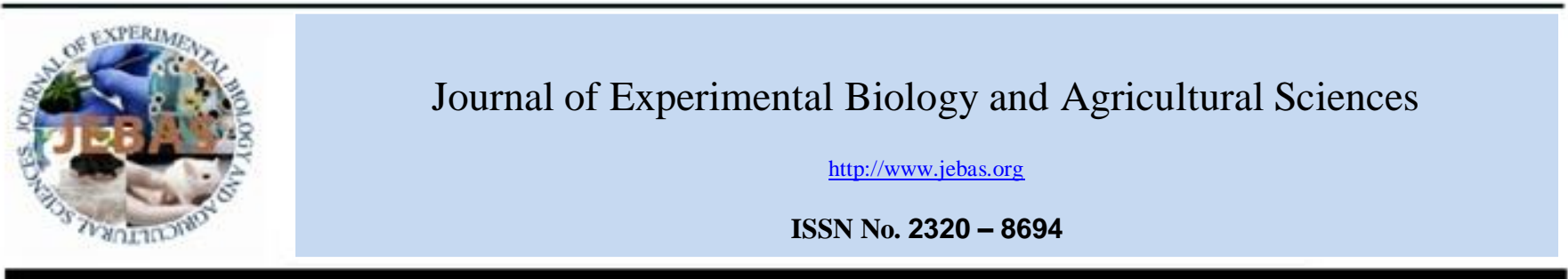

\title{
BIODEGRADATION OF THE AZO DYE (REMAZOL BLACK B) BY Pseudomonas putida ISOLATED FROM TEXTILE WASTEWATER SAMPLE
}

\author{
Samyah D. Jastaniah
}

Biology Department, Faculty of Science, King Abdulaziz University, Saudi Arabia

Received - April 03, 2019; Revision - May 21, 2019; Accepted - June 01, 2019

Available Online - June 10, 2019

DOI: http://dx.doi.org/10.18006/2019.7(3).308.315

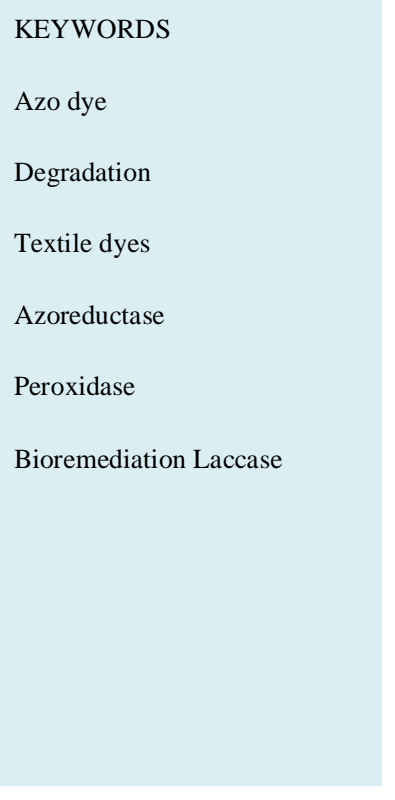

\begin{abstract}
The synthetic aromatic compounds, Azo dyes, which have one or more $-\mathrm{N}=\mathrm{N}-$ groups, are the most important and largest class of the used dyes with commercial applications especially in food and textile industries. The cleaning of textile wastewater containing dyes has attracted much attention in the recent years. The present study is an attempt to determine the ability of some bacterial isolates obtained from textile wastewater sample from $\mathrm{Al}$ Khumra station for decolorization of the Azo dye, Remazol black B. Three bacterial isolates were isolated from wastewater of textile effluents containing azo dye on basal nutrient medium. These isolated bacterial isolates were identified as Bacillus cereus, B. pumilus and Pseudomonas putida by phylogenetic analysis of their $16 \mathrm{~S}$ rDNA. The most promising bacterial isolate was Pseudomonas putida and was used for further study. Results of study revealed that P. putida have ability of complete biodegradation (100\%), if concentration is at $400 \mathrm{ppm}$ while this degradation was 60 and 30 percent at 600 and $700 \mathrm{ppm}$ concentration of azo dye respectively. Further, rate of biodegradation also depend on the $\mathrm{pH}$ and temperature of the surrounding medium, at $400 \mathrm{ppm}$ concentration of azo dye, maximum degradation was obtained at $\mathrm{pH} 6.5$ and temperature $40^{\circ} \mathrm{C}$. This decolorization potential increased the applicability of this bacterium for the dye removal and the results suggest that the obtained isolate of $P$. putida can be used as a useful tool to treat waste water containing Azo dyes. Degradation potential of the bacterium depend on the presence of azoreductases, laccases and peroxidases enzymes.
\end{abstract}

* Corresponding author

E-mail: dr.samyahj@gmail.com (Samyah D. Jastaniah)

Peer review under responsibility of Journal of Experimental Biology and Agricultural Sciences.

Production and Hosting by Horizon Publisher India [HPI] (http://www.horizonpublisherindia.in/).

All rights reserved.
All the articles published by Journal of Experimental Biology and Agricultural Sciences are licensed under a Creative Commons Attribution-NonCommercial 4.0 International License Based on a work at www.jebas.org.

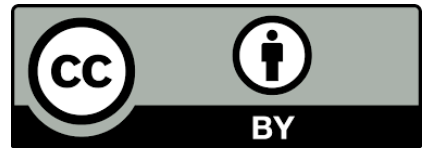




\section{Introduction}

The synthetic Azo dyes are most important class of dye, are widely used as colorants in the textile and food and pharmaceutical industries. These azo pigments are non metalized and metalized colorants; make up 50-60\% of all dyes used by the world colorant industries (Anon, 1996; Aspland, 1997; Corbett, 2000, Lalnunhlimi \& Krishnaswamy, 2016). Some of the Azo dyes are water soluble while rest are water insoluble but solvent soluble. Azo compounds are water-soluble compounds possessing the characteristic $-\mathrm{N}=\mathrm{N}$ - (azo) bond (Figure 1). Water-soluble azo dyes are very important class of dyes for dyeing hydrophilic textiles such as cotton and viscose rayon. Both water soluble and insoluble class of azo dyes have carcinogenic properties and when these dyes are absorbed by human body can undergo decomposition and form amines by the enzymatic activity of body. Currently this includes the 24 amines classified as substances known to be human carcinogens (Waring, 1984; Gregory, 1986; EPA, 1999; Ziarani et al., 2018).

Discharge of untreated Azo dyes contaminated wastewater into<smiles>Nc1c(S(=O)(=O)OCCOS(=O)(=O)O[Na])cc(Nc2cccc(S(=O)(=O)O[Na])c2)c2c1C(=O)c1ccccc1C2=O</smiles>

Figure 1 the chemical structure of Vinyl Sulfone dye, also known as Remazol

environment cause considerable environmental pollution. Various procedures such as filtration, carbon activated, coagulation and chemical flocculation have been widely used to treat dye containing wastewater. Many textile industries have coagulationflocculation and advanced oxidation like azo dye containing wastewater treatment system but these procedures are complex and costly and because of these reasons these methods are not feasible for many countries (Erkurt, 2010; Sivakumar et al., 2013). Furthermore, concentrations of organic matter and particular persistent colorants (dyes) are also affecting the efficiency of treatment procedure (Olejnik \& Wojciechowski, 2012). Kadlec \& Wallace (2009) designed vertical-flow wetlands ecosystems to remove pollutants from wastewater; this system imitates the natural wetlands by relying on heterotrophic microorganisms, aquatic plants, and a combination of naturally occurring processes.

A wide range of microorganism including actinomycetes, bacteria, fungi and yeast have capability to degrade azo dyes in ecofriendly manner (Kirby et al., 2000; Olukanni et al., 2006). These microorganisms' posses various types of azo dyes degrading enzymes such as laccase, azo reductase, peroxidase, and hydrogenase (Khalid et al., 2008; Sudha et al., 2014); these enzymes degrade complex azo dyes in simpler compounds under both aerobic and anaerobic conditions and provide energy to these organisms for their metabolism (Lodato et al., 2007; Sudha et al., 2014). Among the identified microorganisms, due to rapid and easy growth, survival under both aerobic and anaerobic conditions, bacteria is most commonly used for the treatment of azo dyes containing wastewater. Zhang et al. (2010) detected the presence of Klebsiella pneumoniae, Aeromonas hydrophila, Enterobacter cancerogenus, Proteus hauseri and Acinetobacter johnsonii as decolorizers in dye-bearing wastewater from Taiwan. Similarly, Shah et al. (2013) isolated different bacterial isolates having azo dye degrading capability from textile industry wastewater sample. Like this, Hussain et al. (2013) isolated a dye degrading bacterial strain from a textile industry wastewater of Faisalabad, Pakistan in liquid mineral salts medium. Najme et al. (2015) isolated 49 bacterial isolates from industrial waste water which can decolorize various azo dyes like Reactive Orange 16, Reactive Yellow 2 and Reactive Red 120 under the presence of different heavy metals $(\mathrm{Zn}, \mathrm{Cd}, \mathrm{Cr}$, $\mathrm{Pb}$ and $\mathrm{Cu}$ ). Among the isolated bacterial strains, Serratia sp. RN34 had highest ability to decolorize various reactive azo dyes (Yellow2 dye, Red-120 and Orange-16) under static conditions. Bacterial azo dying degrading capacity also depends on the $\mathrm{pH}$ and temperature of wastewater or surrounding mediums. Under static conditions, highest decolorization activity was reported at $\mathrm{pH} 8$ and $25^{\circ} \mathrm{C}$ when yeast extract used as an additional carbon source. The aim of the present study was isolation and identification of some active and local bacterial isolates capable to degrade azo dyes from wastewater treatment plants located at Jeddah, Saudi Arabia.

\section{Materials and Methods}

\subsection{Wastewater sample}

The effluent wastewater sample $(50 \mathrm{ml})$ from wastewater treatment plant, WWTP at Al Khumra in the industrial area, south part of Jeddah, was collected in sterile plastic bottle and transferred directly to laboratory in ice bag for chemical and biological analysis. The $\mathrm{pH}$ and temperature of collected waste water were recorded by standard procedures at sampling site. Different water quality parameters such as Biological Oxidation Demand (BOD), Chemical Oxygen Demand (COD) and Total Suspended Solids (TSS) in addition to Total Dissolved Solids (TDS) were determined by standard protocol (Rainwater \& Thatcher, 1960; USEPA, 1985; APHA, 1992; Rabah et al., 2007). The quantity of sodium in water is known as Sodium adsorption ratio and is measured from the equation given by Lesch \& Suarez (1999).

$$
\mathrm{SAR}=\frac{\mathrm{Na}^{+}}{\sqrt{0.5\left(\mathrm{Ca}^{2+}+\mathrm{Mg}^{2+}\right)}}
$$




\subsection{Preparation Azo dye stock solution}

Vinyl Sulfone dye (trademarked name Remazol® dye "Remazol Black B") is a fiber reactive dye used for silk, wool and cotton coloring, obtained from local market, Jeddah, Saudi Arabia. Stock solution of dye was prepared in de-ionized water $(1000 \mathrm{mg} / \mathrm{l})$ and filter sterilized using $0.45 \mu \mathrm{m}$ filters and used for preparations of different concentration of the dye. The calculated volume of stock dye solution was taken, filter sterilized and added to the sterilized medium.

\subsection{Isolation of bacteria}

About $5 \mathrm{ml}$ of wastewater was added into $250 \mathrm{ml}$ Erlenmeyer flask containing $50 \mathrm{ml}$ of the Mineral Salt broth medium (MSM). The basic composition of MSM broth was: $\mathrm{NaCl}$ $(1 \mathrm{~g} / \mathrm{l}), \quad \mathrm{CaCl}_{2} .2 \mathrm{H}_{2} \mathrm{O}(0.1 \mathrm{~g} / \mathrm{l}), \quad \mathrm{MgSO}_{4} .7 \mathrm{H}_{2} \mathrm{O} \quad(0.5 \mathrm{~g} / \mathrm{l}), \quad \mathrm{KH}_{2} \mathrm{PO}_{4}$ $(1 \mathrm{~g} / \mathrm{l})$ and $\mathrm{Na}_{2} \mathrm{HPO}_{4}(1 \mathrm{~g} / \mathrm{l})$. Medium was also supplemented by Remazol Black B (100 mg/l) and $0.5(\mathrm{~g} / \mathrm{l})$ yeast extract. All flasks having medium along with wastewater were incubated at $30^{\circ} \mathrm{C}$ under static conditions. After 3 days, bacterial cells were collected by centrifugation at $5000 \mathrm{rpm}$ and these were transferred to the fresh medium containing flasks with Remazol Black B $(100 \mathrm{mg} / \mathrm{l})$. After $48 \mathrm{hrs}$ of incubation bacterial growth was estimated and this was followed by the application of 1.0 $\mathrm{ml}$ culture broth on Nutrient Agar containing Remazol Black $(100 \mathrm{mg} / \mathrm{l})$. The colonies exhibiting color removing ability (with clear zones around) were selected, purified and preserved on Nutrient Agar slant at $4^{\circ} \mathrm{C}$ for further studies. Concerning Escherichia coli, it was obtained from King Fahad General Hospital, Jeddah, Saudi Arabia

\subsection{Preculture of the bacterial isolates}

A loopfull of culture of the selected bacteria were inoculated in $250 \mathrm{ml}$ Erlenmeyer flasks containing $50 \mathrm{ml}$ of Nutrient broth medium for 2 days at $30^{\circ} \mathrm{C}$ and $120 \mathrm{rpm}$.

\subsection{Selection of the most active bacterial isolates}

For bacterial selection, the isolates which can tolerate higher concentration of the Azo dye, were selected and maintain on MSM liquid medium supplemented with Remazol Black B (100 $\mathrm{mg} / \mathrm{l})$ and yeast extract $(0.5 \mathrm{~g} / \mathrm{l})$. Each flask was inoculated with $2 \mathrm{ml}$ of bacterial preculture $\left(4 \times 10^{6} \mathrm{CFU} / \mathrm{ml}\right)$. At every $12 \mathrm{hrs}$ intervals, bacterial growth was measured by turbidity $\left(\mathrm{A}_{450 \mathrm{~nm}}\right)$ and the culture broth was centrifuged at 5,000 rpm for 15 minutes. Percent decolorization was monitored by measuring initial and final absorbance at $595 \mathrm{~nm}$ and calculated according to the equation given by Saratale et al. (2009).

Percent Decolorization $=\frac{\text { Initial OD }- \text { Final OD }}{\text { Initial OD }} \times 100$

\subsection{Bacterial growth at different dye concentrations}

To examine the effect of different dye concentration on bacterial growth, $2 \mathrm{ml}\left(4 \times 10^{6} \mathrm{CFU} / \mathrm{ml}\right)$ of best isolate was inoculated in a series of parallel flasks having MSM media supplemented with increased concentrations (100-1000 ppm) of Remazol Black B, these culture flasks were incubated at $30^{\circ} \mathrm{C}$ under static conditions. For estimation of percent degradation and bacterial growth, samples were collected for 3 days at each $12 \mathrm{hrs}$ intervals and the concentration of toxic dye and bacterial growth was estimated as mentioned earlier, uninoculated samples were used as control.

\subsection{Factors affecting decolorization by bacteria}

\subsubsection{Effect of $\mathrm{pH}$ on dye decolorization}

For estimating effect of $\mathrm{pH}$ on dye decolorization, sterile mineral salt broth medium with $400 \mathrm{ppm}$ of Remazol Black B at different $\mathrm{pH}$ values $(4,5,6,6.5,7$, and 8) was prepared in $250 \mathrm{ml}$ Erlenmeyer flasks and $2 \mathrm{ml}$ of the preculture $\left(4 \times 10^{6} \mathrm{CFU} / \mathrm{ml}\right)$ was inoculated in each flask, each treatment was replicated thrice. Uninoculated medium was used as control. All the inoculated and uninoculated flasks were incubated at $30^{\circ} \mathrm{C}$ under static conditions. The percentage decolorization was measured as mentioned earlier.

\subsubsection{Effect of temperature on dye decolorization:}

Erlenmeyer flasks containing $50 \mathrm{ml}$ mineral salt broth medium at $\mathrm{pH} 6.5$ were used to determine the best temperature for dye degradation. The used concentration of the dye was $400 \mathrm{mg} / \mathrm{l}$ and all flasks was inoculated with $2 \mathrm{ml}$ of the preculture $\left(4 \times 10^{6}\right.$ $\mathrm{CFU} / \mathrm{ml}$ ) and were incubated at $25,30,35,40,45$ and $55^{\circ} \mathrm{C}$ for 3 days under static condition. Uninoculated medium was used as control, percentage decolorization was measured at each 12 hours intervals and obtained results were compared with controls.

\subsection{Bacterial identification}

The bacterial isolate which showing highest dye degradation ability was identified by using morphological, physiological, biochemical and molecular studies. Some morphological and physiological characters were determined as per the Bergey's manual of determinative bacteriology. Biochemical tests like Methyl Red, Voges-Proskauer, Indole, Citrate, Catalase, and Oxidase, Nitrate reduction and hydrolysis of Casein, Starch, Urea and Gelatin were also determined. Utilization of different carbon sources, D-glucose, D-fructose, galactose, mannitol and D-maltose and some nitrogen sources were detected at $30^{\circ} \mathrm{C}$ for $24-48 \mathrm{hrs}$.

Crude lysate of cells were prepared, DNA was extracted and subjected to PCR amplification by using the 16S rRNA forward 
primer (5'- AGTTTGATCATGGTCAG-3') and reverse primer (5'-GGTTACCTTGTTACGACT-3'). The primers were designed based on the highly conserved region of 16S rRNA from various bacteria (Weisberg et al., 1991). The amplified PCR product was sequenced using a big dye terminator cycle sequence kit. The product of the sequencing reaction was analyzed using DNA Sequencer ABI PRISM 310 genetic analyzer (Perkin Elmer) and DNA sequence was compared with sequences of some members of the genus available through GenBank database.

\subsection{Statistical analysis}

All decolorization experiments were performed in three sets and mean values were calculated.

\section{Results and Discussion}

Jeddah Bay received massive discharges of partly-treated wastewater, Al Khumra which is a multiport diffuser pipe also contribute in enhancing waste water level of bay (Peña-García et al., 2014). Textile dyeing, leather tanning, paper and sugarcane industries produce large quantities of wastewater which cause serious water pollution not only in rivers, pond or bay but also contaminate groundwater and soil (Abrahart, 1977; Rafi \& Daugherty, 1997; Senan \& Abraham, 2004; Akarslana \& Demiralay, 2015). In current study physico-chemical properties of the collected textile waste effluent were estimated (Table 1). The

Table 1 Chemical and biological analysis of the collected wastewater

\begin{tabular}{|l|c|c|}
\hline Parameter & 6.45 & $6-9$ \\
\hline $\mathrm{pH}$ & $43^{\circ} \mathrm{C}$ & - \\
\hline Temperature & Gray & - \\
\hline Color & 3.30 & $0-3$ \\
\hline $\mathrm{EC}(\mathrm{dS} / \mathrm{m})$ & 36.31 & 30 \\
\hline $\mathrm{NH}_{4}{ }^{+}(\mathrm{mg} / \mathrm{l})$ & 21.48 & - \\
\hline $\mathrm{NO}_{3}{ }^{-}(\mathrm{mg} / \mathrm{l})$ & 4.56 & - \\
\hline $\mathrm{P}^{3-}(\mathrm{mg} / \mathrm{l})$ & 6.60 & 15 \\
\hline $\mathrm{SAR}$ & 1735.40 & 2000 \\
\hline $\mathrm{TDS}(\mathrm{mg} / \mathrm{l})$ & 1134.90 & - \\
\hline $\mathrm{TSS}(\mathrm{mg} / \mathrm{l})$ & 17.32 & - \\
\hline $\mathrm{COD}(\mathrm{mg} / \mathrm{l})$ & 3.48 & - \\
\hline $\mathrm{BOD}(\mathrm{mg} / \mathrm{l})$ & & \\
\hline
\end{tabular}

TS :Total Solids, TDS: Total Dissolved Solids, TSS: Total Suspended Solids, EC = Electrical Conductivity $(\mathrm{dS} / \mathrm{m})$, COD: Chemical Oxygen Demand (mg/l), BOD: Biological Oxygen Demand (mg/l), FAO: Food and Agriculture Organization (1985), -: not detected color of the collected water was dark gray, it was slightly acidic ( $\mathrm{pH}$ 6.45) and have mild temperature. In general, the obtained $\mathrm{pH}$ value fall within the limit $(\mathrm{pH} 7.0$ to 8.5 ) suggested by the World Health Organization (WHO, 1989; DWAF, 1996). Results of present study are in agreement with the findings of Tyagi \& Mehra (1990) while these are contradictory to the findings of Shah (2013) those who reported alkaline nature $(\mathrm{pH} 7.45)$ of waste water, this difference might be because of the nature of pollutant in wastewater. The $\mathrm{pH}$ value of water is very important, as it affects the development of microbial community and other biochemical reactions. Contamination of water by textile pollutant also affects the solubility of gases in water which marked by higher BOD, this higher BOD value indicate the presence of pollutant and higher microbial load in tested water samples (APHA, 1992). Further, electrical conductivity of the collected water samples was reported $3.3 \mathrm{dS} / \mathrm{m}$ while mean COD value was reported $17.32 \mathrm{mg} / \mathrm{l}$. On the other hand, biochemical oxygen demand (BOD) of the collected wastewater sample was reported $3.48 \mathrm{mg} / \mathrm{l}$ and the value of total suspended solids (TSS) were found $1134.9 \mathrm{mg} / \mathrm{l}$. The concentrations of $\mathrm{NH}_{4}{ }^{+}, \mathrm{NO}_{3}{ }^{-}$and $\mathrm{P}^{3-}$ were found $36.31,21.48$ and 4.56, mg/l, respectively (Table 1 ). In the present study, BOD value was reported lower than the permissible limits. Lokhande et al. (2011) reported higher BOD values (1047.3 $\mathrm{mg} / \mathrm{L}$ ) for the water sample collected from pharmaceutical industries while it was reported $776.2 \mathrm{mg} / \mathrm{l}$ and $535.8 \mathrm{mg} / \mathrm{L}$ for the samples collected from dyes and paint industries. In present study electrical conductivity was reported higher than that recommended concentration (0-3.0) of FAO (1985), which means collected water samples are not good for general use (Abdo et al., 2010). It was well known that wastewater contained many nutrients and ions especially nitrate $\left(\mathrm{NO}_{3}{ }^{-}\right)$, affecting the plant growth adversely (Magesan, 2001). In present study, sodium adsorption ratio (SAR) was reported 6.60 which is very higher the recommended limit and it indicate the unsuitability of this water for irrigation and cultivation purpose. Further, TDS is high for the collected samples which reduce purification of wastewater by microorganisms (Jiunkins, 1982; Kim, 1994).

The water samples collected from wastewater treatment plant of Al Khumra, industrial area, were spread on mineral salt broth medium containing $100 \mathrm{ppm}$ of the Remazol dye. Bacterial colonies surrounded by clear zone were consider as an effective strain and were selected for further study related to the azo dye removal capability; total three bacterial isolates were selected and isolated. These isolated isolates were characterized and identified according to Bergey's Manual of 
Systematic Bacteriology, physiological and biochemical tests (Holt et al., 1993; Harrigan, 1998), these isolated strains were identified as Bacillus pumils ABO23, Bacillus cereus ABO13 and Pseudomonas putida ABO23. Among these, Bacillus pumils $\mathrm{ABO} 23$, B. cereus $\mathrm{ABO} 13$ were Gram positive spore forming bacteria while $P$. putida $\mathrm{ABO} 23$ was gram negative, rod shape, non spore forming bacterium. Identification was confirmed by using 16 rRNA studies and phylogenic trees of the selected bacteria compared with available genera database (Figures 2 and 3). Figure 4 showed the percentages of decolorization by the selected three most promising bacteria isolates, grown on broth medium supplemented with $100 \mathrm{ppm}$ of Remazol B for 3 days, and these results were compared with E. coli. Further, the decolorization percentages after 72 hours were 100, 80 and 72 percent for P. putida ABO23, Bacillus cereus $\mathrm{ABO} 13$ and B. pumils $\mathrm{ABO} 23$, respectively while it was less than $20 \%$ in case of E. coli. Figure 5 represents the percentage decolorization by the $P$. putida $\mathrm{ABO} 23$ grown on broth medium containing increasing concentrations of Remazol black B for 3 days. The percentage of degradation was 100 percent up to $400 \mathrm{ppm}$ concentration of Remazol black B and afterword increasing concentration of Remazol black B decreased degradation. At 700 ppm, decolorization percentage was less than 30 percent after $72 \mathrm{hrs}$ of inoculation (Figure 5). Effect of $\mathrm{pH}$ and temperature was also evaluated in present study and maximum decolorization percentage was recorded at $\mathrm{pH} 6.5$ and temperature $40^{\circ} \mathrm{C}$ whereas $100 \%$ decolorization was found after $60 \mathrm{hrs}$ instead of $72 \mathrm{hr}$ at $\mathrm{pH} 7$ and $30^{\circ} \mathrm{C}$ (Figure $6 \& 7$ ). The $\mathrm{pH}$ value of the medium affect degradation of the dye and maximum

\section{Bacillus pumilus ABO23}

\section{Bacillus cereus}

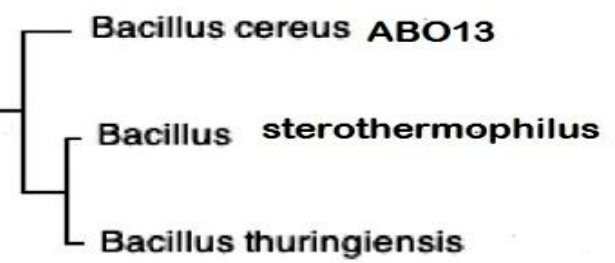

Figure 2 Phylogenic relationship between Bacillus pumils $\mathrm{ABO} 23$, B. cereus $\mathrm{ABO} 13$ and other related reference isolates based on the 16S rRNA gene sequence analysis

decolorization percentage was reported at $\mathrm{pH} 6.5$ but this dye degradation percentage reduced at $\mathrm{pH} 6$ and 7 and the lowest percentages were at $\mathrm{pH} \mathrm{4,5}$ and 8 (Figure 6). Findings of present study are in agreement with the findings of Chang et al. (2001) and Shah et al. (2013). Similarly, Aburas (2016) isolated $P$. putida from waste water sample and reported highest ability of PHB production. Azo dye degradation was enhanced by alkaliphilic bacterial consortium (Mahmoud et al., 2017) or by special fungal degradation including Aspergillus niger strain isolated from textile wastewater. Bioremediations of contaminants and toxins using bacteria has been intensified and reported by many authors (Dawkar et al., 2008; Singh et al., 2014). Similarly, Roy et al. (2018) reported that bioremediation of industrial effluent containing textile dyes using bacteria is an emerging and important tool in

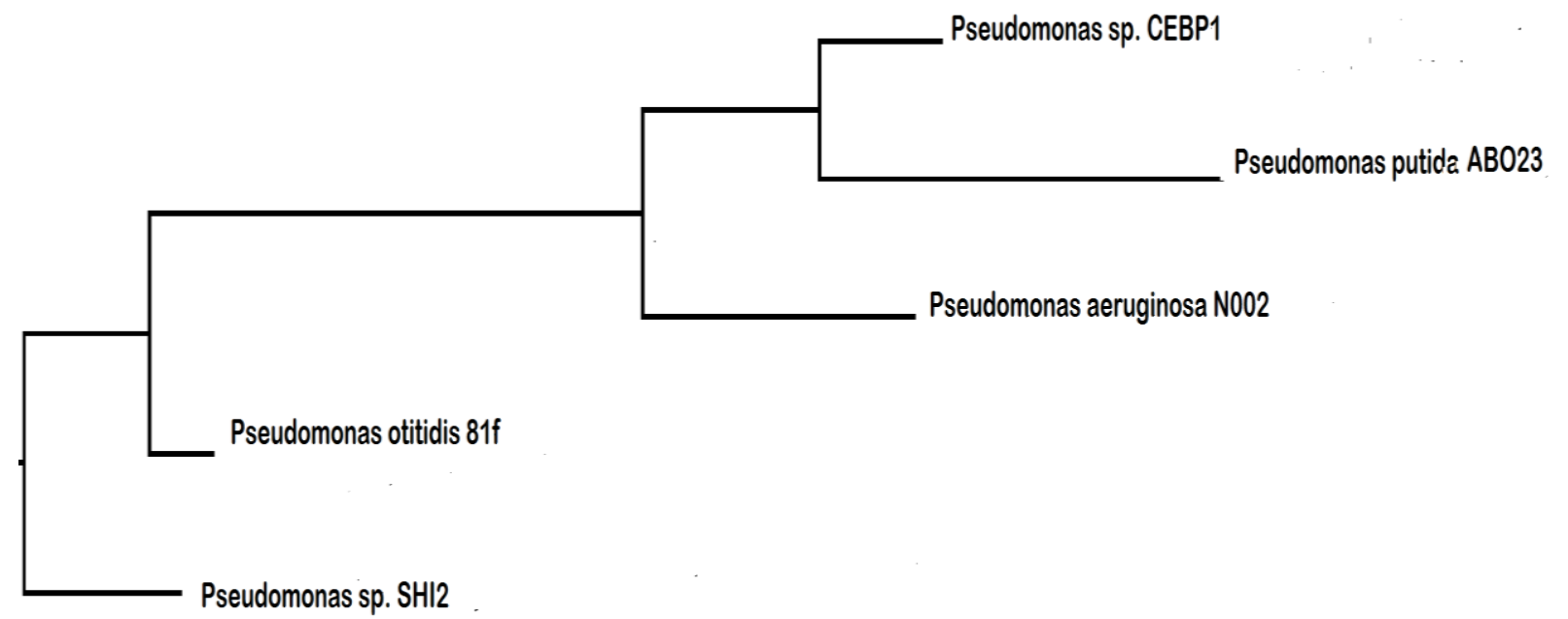

Figure 3 Phylogenic relationship between Pseudomonas putida and other related reference isolates based on the 16S rRNA gene sequence analysis 


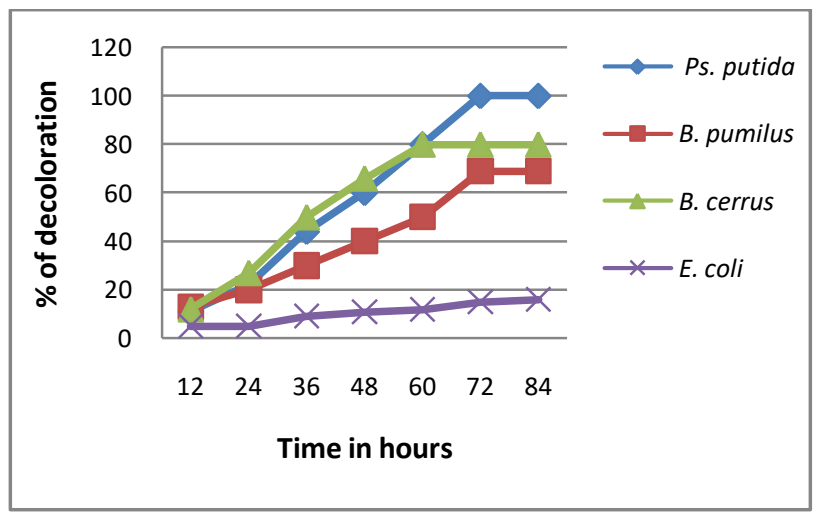

Figure 4 Percent decolorization of the three bacteria isolates grown on broth medium supplemented with Remazol B for 3 days and results compared with $E$. coli

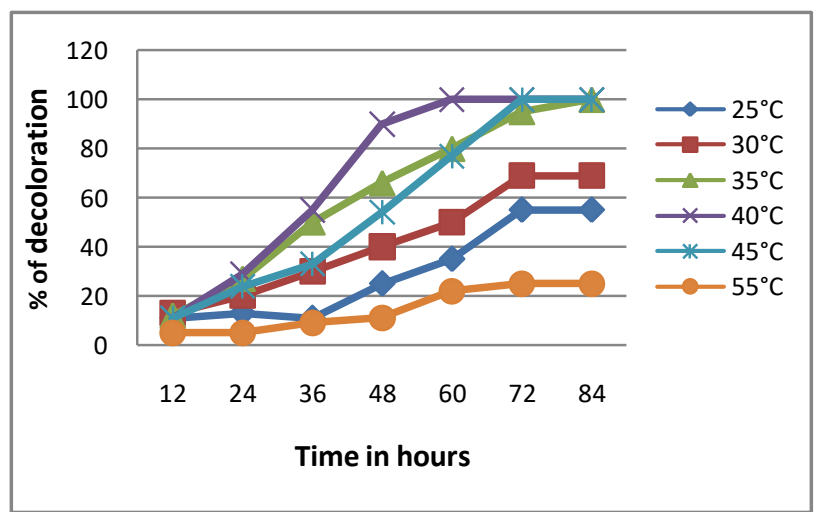

Figure 6 Effect of temperature on degradation of Remazol Black B by the selected $P$. putida $\mathrm{ABO} 23$

environmental protection and pollution treatment. In conclusion, industrial effluent containing textile dyes was considered as mutagenic and mitotic poisoning water and bioremediation of these toxic materials by bacteria, is becoming an emerging and important technique. All three selected bacterial isolates from the textile effluent showed excellent decomposition and decolorization of the textile Azo dye. Among these P. putida reported most potent one under the best conditions for bioremediation process.

\section{Conflict of interests}

There is no conflict of interest.

\section{References}

Abdo MH, Sabae SZ, Haroon BM, Refaat BM, Mohammed AS (2010) Physico-chemical characteristics, microbial assessment

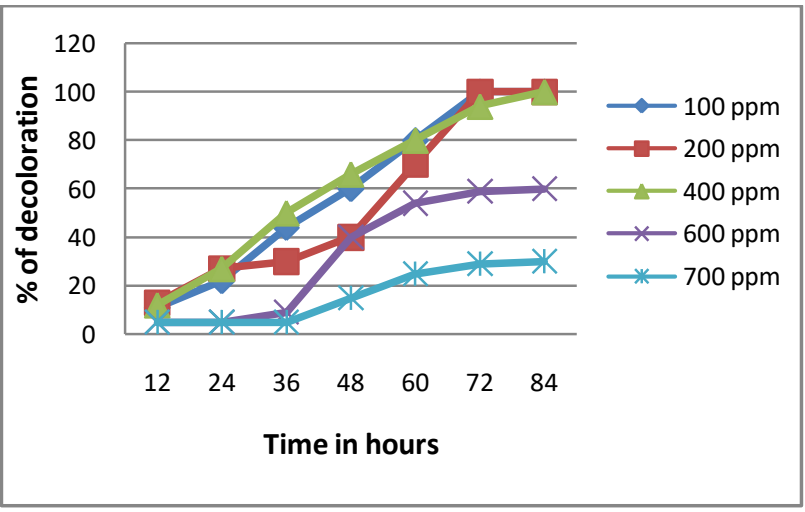

Figure 5 Percent decolorization by the selected $P$. putida ABO23, grown for 3 days on broth medium containing increasing concentrations of Remazol B

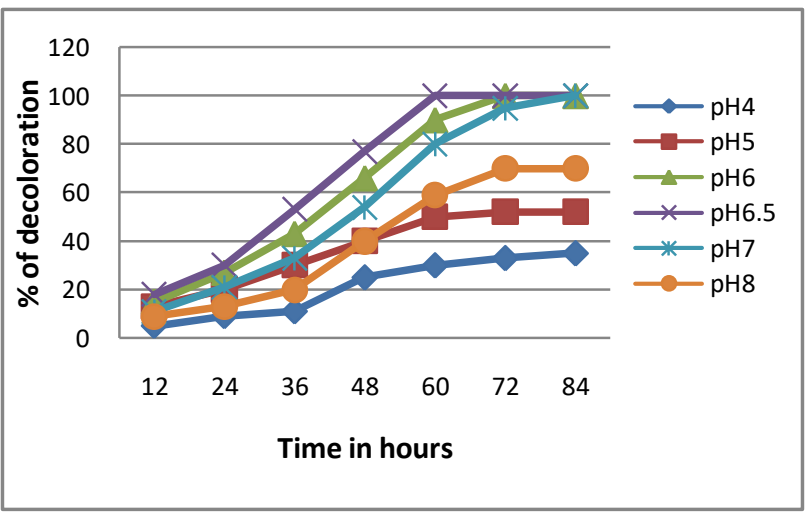

Figure 7 Effect of $\mathrm{pH}$ on degradation of Remazol Black B by the selected $P$. putida ABO23

and antibiotic susceptibility of pathogenic bacteria of Ismailia canal water, River Nile, Egypt. Journal of American Science 6: 234-250.

Abrahart EN (1977) Dyes and their Intermediates. New York: Chemical Publishing, Pp. 1-12.

Aburas MMA (2016) Production of poly $\beta$ hydroxybuthyrate from Pseudomonas putida MAO12 isolated from wastewater sample. Journal of American Science $12: 107-112$.

Akarslana F, Demiralay H (2015) Effects of textile materials harmful to human health. Acta Physica Polonica A No. 2-B Vol. 128: 407-408.

Anon M (1996) Ecological and Toxicological Association of Dyes and Pigments Manufacturers, Textile Chemists and Colorist, "German Ban of Use of Certain Azo Compounds in Some Consumer Goods: ETAD Information Notice No. 6", 28: 11. 
APHA (1992) Standard methods for the examination of water and wastewater. $18^{\text {th }}$ ed. American Public Health Association, Washington, DC.

Aspland JR (1997) Textile Dyeing and Coloration. Association of Textile Chemists and Colorists, Pp. 3-310.

Chang JS, Chou C, Chen SY (2001) Decolorization of azo dyes with immobilized Pseudomonas luteola. Process Biochemistry 36: 757-763.

Corbett J (2000) Hair Dyes. In: Freeman HS, Peter AT (Eds.), Colorants for Non-textile Applications, Amsterdam: Elsevier Science, Pp. 456-477.

Dawkar V, Jadhav U, Jadhav S, Govindwar S (2008) Biodegradation of disperse textile dye Brown 3REL by newly isolated Bacillus sp. VUS. Journal of Applied Microbiology105: 14-24.

DWAF (1996) Department of Water Affairs and Forestry, South African water quality guidelines. Volume 7. Aquatic ecosystems. Pretoria, South Africa.

Environmental protection agency (1999) Survey of azo -colorants in Denmark. Consumption, use, health and environmental aspects. www. statensnet.dk/pligtarkiv/fremvis.pl?vaerkid $=4601 \&$ reprid $=0$ \&filid $=0 \&$ iarki

Erkurt HA (2010) Biodegradation of Azo Dyes. In: Barcelo D; Kostianoy AG (Eds.), The Hand Book of Environmental Chemistry, 9th Ed. Springer Verlag Berlin Heidelberg. Pp. 1-37.

FAO (1985) A Guide to Forest Seed Handling. FAO Forestry Paper 20/2. FAO, Rome.

Gregory P (1986) Azo dyes: structure-carcinogenicity relationships. Dyes and Pigments 7:45-56 doi:10.1016/01437208(86)87005-X.

Harrigan WF (1998) Laboratory Methods in Food Microbiology (3rd ed.) Academic Press, San Diego Pp. 198.

Holt JG, Krieg NR, Sneath PH, Safety JT, Williams ST (1993) Bergey's Manual of Determinative Bacteriology. In: Williams K, Wilkins O (Eds.), Baltimore, USA, Pp.9.

Hussain S, Maqbool Z, Ali S, Yasmeen T, Imran M, Mahmood F, Abbas F (2013) Biodecolorization of Reactive Black-5 by a metal and salt tolerant bacterial strain Pseudomonas sp. RA20 isolated from Paharang drain effluents in Pakistan. Ecotoxicology and Environmental Safety 98:331-8.
Jiunkins R (1982) Pretreatment of textile waste water. Proceeding of the $37^{\text {th }}$ Industrial waste Conference Purdue University, Lafayette, Indiana Pp. 37-139.

Kadlec RH, Wallace SD (2009) Treatment Wetlands, 2nd Ed. CRC Press, Taylor \& Francis Group, Boca Raton, US.

Khalid A, Arshad M, Crowley DE (2008) Decolorization of azo dyes by Shewanella sp. Under saline conditions. Applied Microbiology and Biotechnology 79:1053- 1059.

Kim HT (1994) Soil Reaction. In: Environmental Soil Science. Marcel Dekker Inc., U.S.A, Pp. 149.

Kirby N, Marchant R, McMullan G (2000) Decolorisation of synthetic textile dyes by Phlebia tremellosa. FEMS Microbiology Letters 1881:93-96.

Lalnunhlimi S, Krishnaswamy V (2016) Decolorization of azo dyes (Direct Blue 151 and Direct Red 31) by moderately alkaliphilic bacterial consortium. Brazilian Journal of Microbiology 47:39-46.

Lesch M, Suarez DL (1999) A short note on calculating the adjusted SAR index. Ecotoxicology and Environmental Safety 52: 493-496.

Lodato A, Alfieri F, Olivieri G, Di Donato A, Marzocchella A, Salatino P (2007) Azo-dye convention by means of Pseudomonas sp. OXI. Enzyme and Microbial Technology 41:646-652.

Lokhande RS, Singare PU, Pimple D S (2011) Study on physico-chemical parameters of waste water effluents from Taloja industrial area of Mumbai, India. International Journal of Ecosystem 1: 1-9.

Magesan GN (2001) Changes in soil physical properties after irrigation of two forested soils with municipal wastewater. New Zealand Journal of Science 31:188-195.

Mahmoud MS, Mostafa MK, Mohamed SA, Sobhy NA, Nasr M (2017). Bioremediation of red azo dye from aqueous solutions by Aspergillus niger strain isolated from textile wastewater. Journal of Environmental Chemical Engineering, 5:547-554.

Najme R, Hussain S, Maqbool Z, Imran M, Mahmood F, Manzoor H, Yasmeen T, Shehzad T (2015) Biodecolorization of reactive yellow-2 by Serratia sp. RN34 isolated from textile wastewater. Water Environment Research 87:2065-2075.

Olejnik D, Wojciechowski K (2012) The conception of constructed wetland for dyes removal in water solutions. Chemik Science-Technique-Market 66: 611-614. 
Olukanni OD, Osuntoki AA, Gbenle GO (2006) Textile effluent biodegradation potentials of textile effluent adapted and non adapted bacteria. African Journal of Biotechnology 5: 1980-1984.

Peña-García D, Ladwig N, Turki AJ, Mudarris MS (2014) Input and dispersion of nutrients from the Jeddah Metropolitan Area, Red Sea. Marine Pollution Bulletin 80: 41-51

Rabah S, Azab E, Aly M (2007) Studies on bacterioplankton and inhibitory strains of actinomycetes in lake Bardawil, Egypt. World Journal Microbiology Biotechnology, 23: 167-176.

Rafi F, Daugherty JE (1997) Assessment of chemical exposures: Calculation methods for environmental professionals, Chemical Rubber Company, Press, Pp. 456.

Rainwater FH, Thatcher LL (1960) Methods for Collection and Analysis of Water Samples, U.S. Geol. Surv. Water Supply Papers 1454: 1-301

Roy DC, Biswas SK, Saha AK, Sikdar B, Rahman M, Roy AK, Prodhan ZH, Tang SS (2018). Biodegradation of Crystal Violet dye by bacteria isolated from textile industry effluents. Peer Journal 21:6:e5015.

Saratale RG, Saratale GD, Chang JS, Govindwar SP (2009) Ecofriendly degradation of sulphonated diazo dye C.I. Reactive Green 19A using Micrococcus glutamicus NCIM-2168. Bioresource Technology 100: 3897-3905.

Senan RC, Abraham TE (2004) Bioremediation of textile Azo dyes by aerobic bacterial consortium. Biodegradation 15: 275-80.

Shah M P (2013) Microbial degradation of textile dye (Remazol Black B) by Bacillus spp. ETL-2012. Journal of Applied and Environmental Microbiology 1: 6-11.

Shah MP, Sebastian S, Mathukiya HM, Darji AM, Patel J, Patel K (2013) Selection of bacterial strains efficient in decolorization of remazol black-B. Roumanian Archives of Microbiology and Immunology, 72: 234-41.
Singh R P, Singh PK, Sing R L (2014) Bacterial Decolorization of Textile Azo Dye Acid Orange by Staphylococcus hominis RMLRT03. Toxicology International, 21: 160-166.

Sivakumar D, Shankar D, Vijaya Prathima AJ, Valarmathi M (2013) Constructed wetland treatment of textile industry wastewater using aquatic macrophytes. International Journal of Environmental Science and Technology 3:1223-1232.

Sudha M, Saranya A, Selvakumar G, Sivakumar N (2014) Microbial degradation of Azo Dyes: A review. International journal of Current Microbiology and Applied Sciences 3: 670-690.

Tyagi OD, Mehra M (1990) A textbook of environmental chemistry. Anmol Publications, New Delhi, India

USEPA (1985) Test methods for Escherichia coli and enterococci in water by the membrane filter procedure (Method \#1103.1), EPA 600/4-85-076. U.S.

Waring DR (1984) Heterocyclic Dyes and Pigments. In: Katritzky AR, Rees CW (Eds), Comprehensive Heterocyclic Chemistry, Elsevier Publication, Pp 317-346 https://doi.org/10.1016/B978008096519-2.00012-6.

Weisberg WG, Barns SM, Pelletier DA, Lane DJ (1991) 16S ribosomal DNA amplification for phylogenetic study. Journal of Bacteriology 173: 697-703.

WHO (1989) Health guidelines for the use of wastewater in agriculture and aquaculture. Report of a WHO Scientific Group. Geneva, (Technical Report Series, No. 778).

Zhang MM, Chen WM, Chen BY, Chang CT, Hsueh CC, Ding Y, Lin KL, Xu H (2010) Comparative study on characteristics of azo dye decolorization by indigenous decolorizers. Bioresource Technology 101:2651-2656.

Ziarani GM, Moradi R, Lashgari N, Kruger HG (2018) Azo Dyes. In: Metal-Free Synthetic Organic Dyes, Elsevier Publication, Pp. 47-93. DOI: https://doi.org/10.1016/C2017-0-03672-8. 